Article

\title{
Application of a Keplerate type giant nanoporous isopolyoxomolybdate as a reusable catalyst for the synthesis of 1,2,4,5-tetrasubstituted imidazoles
}

\author{
Ahmad Nakhaei, Abolghasem Davoodnia* \\ Department of Chemistry, Mashhad Branch, Islamic Azad University, Mashhad, Iran
}

\section{A R T I C L E I N F O}

Article history:

Received 21 April 2014

Accepted 9 June 2014

Published 20 October 2014

\section{Keywords:}

Giant Nanoporous

isopolyoxomolybdate

Keplerate

Solvent-free condition

1,2,4,5-tetrasubstituted imidazole

\begin{abstract}
A B S T R A C T
The Keplerate-type giant nanoporous isopolyoxomolybdate $\left(\mathrm{NH}_{4}\right)_{42}\left[\mathrm{Mo}^{\mathrm{VI}_{72} \mathrm{MoV}_{60} \mathrm{O}_{372}-}\right.$ $\left.\left(\mathrm{CH}_{3} \mathrm{COO}\right)_{30}\left(\mathrm{H}_{2} \mathrm{O}\right)_{72}\right]$, denoted $\left\{\mathrm{Mo}_{132}\right\}$, has been used as a catalyst for the synthesis of 1,2,4,5-tetrasubstituted imidazoles by the one-pot, four-component thermal reaction of benzil with aromatic aldehydes, primary amines, and ammonium acetate under solvent-free conditions. The catalyst was prepared according to a previously published literature procedure using inexpensive and readily available starting materials, and subsequently characterized by FT-IR, UV and X-ray diffraction spectroscopy, as well as microanalysis. The results showed that $\left\{\mathrm{Mo}_{132}\right\}$ exhibited high catalytic activity towards the synthesis of 1,2,4,5-tetrasubstituted imidazoles, with the desired products being formed in good to high yields. Furthermore, the catalyst was recyclable and could be reused at least three times without any discernible loss in its catalytic activity. Overall, this new catalytic method for the synthesis of 1,2,4,5-tetrasubstituted imidazoles provides rapid access to the desired compounds following a simple work-up procedure, and avoids the use of harmful organic solvents. This method therefore represents a significant improvement over the methods currently available for the synthesis of tetrasubstituted imidazoles.
\end{abstract}

(C) 2014, Dalian Institute of Chemical Physics, Chinese Academy of Sciences. Published by Elsevier B.V. All rights reserved.

\section{Introduction}

Polyoxometalates (POMs) are a large class of metal oxide cluster compounds consisting of transition metal atoms bridged by oxygen atoms. POMs can exist in a variety of different size and structure, and compounds belonging to this class have been studied extensively because they possess interesting electronic and molecular properties, such as wide-ranging redox potentials, acidities, polarities, and solubilities. Based on their attractive properties, POMs have also been used in a variety of different application, including catalysis, biomedicine, magnetism, nanotechnology and materials science [1-4]. There has been a growing interest during the last few years in the synthesis of nanotubular materials containing POMs such as POM-based titanium nanotubes [5] and POM-organic hybrid nanotubes [6]. These new types of nanotubes possess the functional properties of POMs as well as some of the key advantages associated with tubular systems, including, for example, enhanced catalytic and photochemical properties [5-7].

Müller et al. [8] famously reported the discovery of giant nanosized porous Keplerate-type POMs. The Keplerate and giant nanosized porous POMs possess unique features and properties that could allow them to be considered as the basis for a new area of nanochemistry and nanomaterials science $[9,10]$. These materials have also found numerous application in fundamental and applied sciences, where they have been

\footnotetext{
* Corresponding author. Tel: +98-511-8435000; Fax: +98-511-8424020; E-mail: adavoodnia@mshdiau.ac.ir, adavoodnia@yahoo.com DOI: 10.1016/S1872-2067(14)60174-1 | http://www.sciencedirect.com/science/journal/18722067 | Chin. J. Catal., Vol. 35, No. 10, October 2014
} 
used to model passive cation transport through membranes, as well as being evaluated in terms of their encapsulation, nanoseparation chemistry, magnetic and optical properties [11,12]. Despite their many valuable properties, there has, to the best of our knowledge, been only one report in the literature pertaining to the use of giant nanosized porous POMs as catalysts, where they were used to catalyze the epoxidation of olefins [13]. Furthermore, there have been no reports concerning the use of POMs as catalysts for multicomponent reactions.

The imidazole ring system is an important nitrogen-containing substructure that plays an important role in numerous biochemical processes, and this system can be found in a large number of natural products and pharmacologically active compounds [14]. Multisubstituted imidazoles are biologically active, and several compounds containing systems of this type have been reported to possess interesting biological properties, including antibacterial [15], analgesic [16] and glucagon receptor antagonism [17] activity. Several substituted imidazoles have also been reported as inhibitors of p38 MAP kinase [18] and B-Raf kinase [19]. Furthermore, recent advances in green chemistry and organometallic catalysis have extended the application of imidazoles as ionic liquids [20-22] and $\mathrm{N}$-heterocyclic carbenes [23]. Despite the availability of a wide variety of synthetic routes for the construction of imidazoles, very few methods exist for the synthesis of 1,2,4,5-tetrasubstituted imidazoles. These compounds are generally synthesized via the four-component reaction of 1,2-diketones or $\alpha$-hydroxyketones with aldehydes, primary amines, and ammonium acetate in the presence of a catalyst such as L-proline [24],

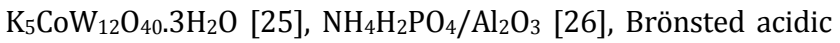
ionic liquid [27], $\mathrm{BF}_{3}-\mathrm{SiO}_{2}$ [28], carbon-based solid acid [29], $\mathrm{InCl}_{3 .} 3 \mathrm{H}_{2} \mathrm{O}$ [30], $\mathrm{NaHSO}_{4} / \mathrm{SiO}_{2}$ [31], $\mathrm{H}_{6} \mathrm{P}_{2} \mathrm{~W}_{18} \mathrm{O}_{62} .24 \mathrm{H}_{2} \mathrm{O} / \mathrm{SiO}_{2}$ [32], $\mathrm{FeCl}_{3} /$ montmorillonite $\mathrm{K} 10$ under microwave irradiation [33], $p$-dodecylbenzenesulfonic acid [34], and montmorillonite K10 supported titanium [35]. 1,2,4,5-Tetrasubstituted imidazoles can also be accessed by the hetero-Cope rearrangement or the $\mathrm{N}$-alkylation of trisubstituted imidazoles [36,37]. However, some of these synthetic methods have been limited in terms of their application because of poor yields or their requirement for expensive catalysts, long reaction time, and tedious isolation procedures. With this in mind, there is therefore an urgent need for the development of a new environmentally friendly method using an inexpensive catalyst with high catalytic activity for the synthesis of 1,2,4,5-tetrasubstituted imidazoles.

As a result of our interest in the synthesis of heterocyclic compounds [38-41], and as part of our ongoing research towards the development of environmentally friendly methods for the synthesis of organic compounds using reusable catalysts [42-48], we report herein the use of the Keplerate type giant nanoporous isopolyoxomolybdate, $\left(\mathrm{NH}_{4}\right)_{42}\left[\mathrm{MoVI}_{72} \mathrm{MoV}_{60} \mathrm{O}_{372-}\right.$ $\left.\left(\mathrm{CH}_{3} \mathrm{COO}\right)_{30}\left(\mathrm{H}_{2} \mathrm{O}\right)_{72}\right]$, denoted as $\left\{\mathrm{Mo}_{132}\right\}$ (Fig. 1), as a novel catalyst for the efficient solvent-free synthesis of 1,2,4,5tetrasubstituted imidazoles. This new process allows for the one-pot synthesis of 1,2,4,5-tetrasubstituted imidazoles by the four-component condensation of benzil (1) with an aromatic aldehyde (2), primary amine (3), and ammonium acetate (4). The diameter of this ball-shaped POM was reported to be 2.9

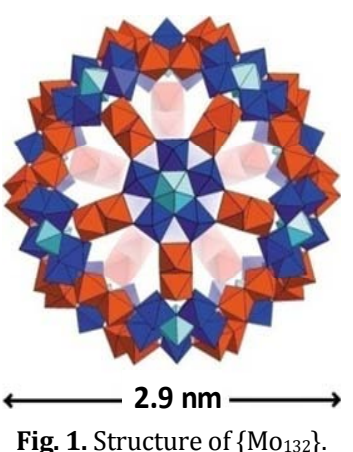

nm based on theoretical calculations [8,9]. Polarz et al. [10] were the first group to report the characterization of the molybdenum cluster using TEM. The TEM picture clearly showed that the clusters possessed a periodic structure with an average diameter of approximately $3 \mathrm{~nm}$. This experimentally determined diameter was in good agreement with the theoretical value for the inner diameter of the ball-shaped POM $[8,9]$.

\section{Experimental}

\subsection{Synthesis of the Keplerate $\left\{\mathrm{Mo}_{132}\right\}$}

$\mathrm{N}_{2} \mathrm{H}_{4} \cdot \mathrm{H}_{2} \mathrm{SO}_{4}(0.8 \mathrm{~g}, 6.1 \mathrm{mmol})$ was added to a solution of $\left(\mathrm{NH}_{4}\right)_{6} \mathrm{Mo}_{7} \mathrm{O}_{24} \cdot 4 \mathrm{H}_{2} \mathrm{O}(5.6 \mathrm{~g}, 4.5 \mathrm{mmol})$ and $\mathrm{CH}_{3} \mathrm{COONH}_{4}(12.5 \mathrm{~g}$, $162.2 \mathrm{mmol})$ in $\mathrm{H}_{2} \mathrm{O}(250 \mathrm{ml})$, and the resulting solution was stirred for $10 \mathrm{~min}$, during which time it became blue-green in color. The mixture was then treated with $50 \% \mathrm{CH}_{3} \mathrm{COOH}(83$ $\mathrm{ml}$ ) to give a green solution, which was stored in an open 500-ml Erlenmeyer flask at $20{ }^{\circ} \mathrm{C}$ without stirring. It is noteworthy that the solution became dark brown in color on standing. Following $4 \mathrm{~d}$ of storage under these conditions, the mixture was filtered to give red-brown crystals, which were washed sequentially with absolute ethanol and diethyl ether, before being dried in air [8].

\subsection{General procedure for the synthesis of 1,2,4,5-tetrasubstituted imidazoles $\mathbf{5 a - 5 m}$}

A mixture of benzil 1 (1 mmol), aromatic aldehyde 2 (1 mmol), primary amine 3 (1 mmol), ammonium acetate 4 (1 mmol), and $\{$ Mo132 $\}$ ( $0.1 \mathrm{~g}$ ) was heated in the oil bath at $140{ }^{\circ} \mathrm{C}$ for 20-90 min. Upon completion of the reaction, as determined by thin-layer chromatography (TLC), the mixture was diluted with hot ethanol and then filtered to remove the catalyst. The catalyst was then washed with a small portion of hot ethanol $(10 \mathrm{ml})$, and the combined filtrates were concentrated in volume (by half) and allowed to stand at room temperature until precipitation occurred. The resulting precipitate was collected by filtration, and recrystallized from ethanol to give compounds $\mathbf{5 a - 5 m}$ in high yields (Scheme 1). The melting points were recorded using a Stuart SMP3 melting point apparatus. The FT-IR spectra of the products were recorded on a Tensor 27 Bruker spectrophotometer as $\mathrm{KBr}$ disks. The ${ }^{1} \mathrm{H}$ NMR spectra were recorded on Bruker 400 and 500 spectrometers at 400 and $500 \mathrm{MHz}$, respectively. 


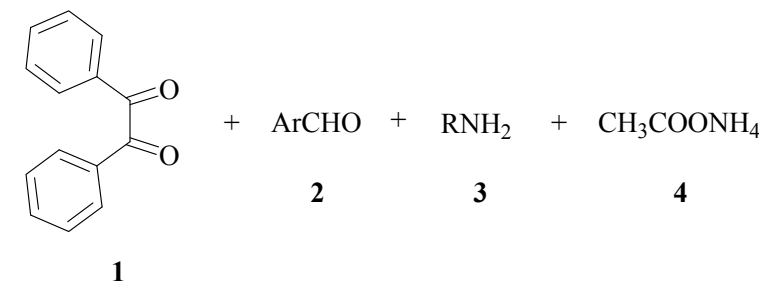

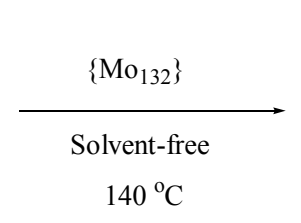

$140{ }^{\circ} \mathrm{C}$

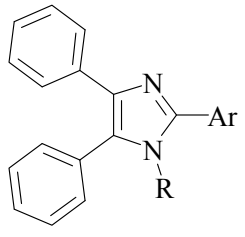

$5 a-5 m$

Scheme 1. $\left\{\mathrm{Mo}_{132}\right\}$ catalyzed synthesis of 1,2,4,5-tetrasubstituted imidazoles.

\section{Results and discussion}

\subsection{Characterized results of $\left\{\mathrm{Mo}_{132}\right\}$}

The $\{$ Mo132 $\}$ catalyst was characterized by FT-IR, UV/Vis, and X-ray diffraction (XRD) spectroscopy, as well as microanalysis. The FT-IR spectrum of the catalyst is shown in Fig. 2(1) and contains the characteristic vibrational bands of the $\mathrm{Mo}=0$ bond at 969 and $936 \mathrm{~cm}^{-1}$, as well bands belonging to the COOand $\mathrm{NH}_{4}{ }^{+}$groups at 1544 and $1406 \mathrm{~cm}^{-1}$, respectively. The FT-IR spectrum of the catalyst also contained bands at 2500-3600 and $1618 \mathrm{~cm}^{-1}$, which indicated the presence of water. Pleasingly, the FT-IR spectrum of the $\left\{\mathrm{Mo}_{132}\right\}$ catalyst prepared in the current study was consistent with those reported by Müller' [8] and Zhou' [9] groups. The UV/Vis spectrum of the $\left\{\mathrm{Mo}_{132}\right\}$ catalyst provided further confirmation of its structure, and the characteristic absorption bonds at 213 , 232, 265, and $447 \mathrm{~nm}$ were consistent with those reported in the literature [8]. The XRD pattern of $\left\{\mathrm{Mo}_{132}\right\}$ catalyst (Fig. 3)

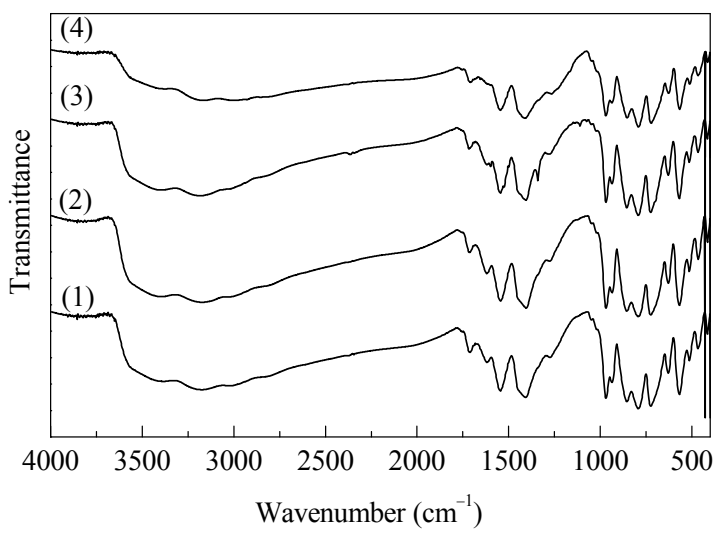

Fig. 2. FT-IR spectra of the fresh catalyst $\left\{\mathrm{Mo}_{132}\right\}$ ((1), first run), and the recovered catalyst ((2-4), runs 2-4).

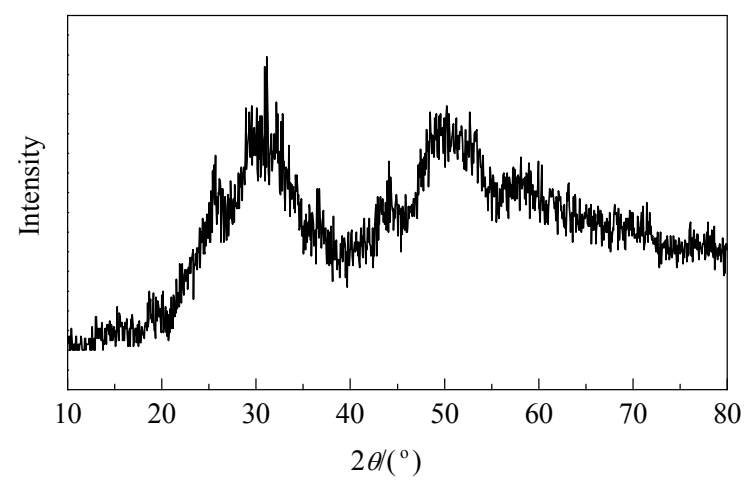

Fig. 3. XRD pattern of $\left\{\mathrm{Mo}_{132}\right\}$. revealed five diffraction peaks at $2 \theta=19.3218^{\circ}, 25.8040^{\circ}$, $30.2125^{\circ}, 44.1001^{\circ}$, and $50.2848^{\circ}$. Furthermore, elemental analysis of the $\left\{\mathrm{Mo}_{132}\right\}$ catalyst gave satisfactory data, which corresponded to a molecular formula of $\mathrm{C}_{60} \mathrm{H}_{402} \mathrm{Mo}_{132} \mathrm{~N}_{42} \mathrm{O}_{504}$ (Calcd.: C 3.21\%, H 1.81\%, N 2.62\%; found: C 3.30\%, H 1.92\%, N 2.49\%).

\subsection{Evaluation of catalytic activity of $\left\{\mathrm{Mo}_{132}\right\}$ towards the reaction}

The catalytic activity of $\{$ Mo132 $\}$ was evaluated in the synthesis of 1,2,4,5-tetrasubstituted imidazoles. The synthesis of compound $\mathbf{5 b}$ by the four-component reaction of benzil (1 mmol) with 4-chlorobenzaldehyde ( $1 \mathrm{mmol})$, aniline $(1 \mathrm{mmol})$, and ammonium acetate (1 mmol) was initially selected as a model reaction to optimize the reaction conditions. Several reaction parameters were evaluated during this optimization stage, including the loading of the $\left\{\mathrm{Mo}_{132}\right\}$ catalyst, the temperature of the reaction, and the reaction solvent (Table 1). It is clear from the results shown in Table 1 that the shortest reaction time and best yield were achieved under solvent-free conditions (Table 1, entry 14). These results also revealed that the loading of the catalyst and the reaction temperature had a significant impact on the yield of compound $\mathbf{5 b}$ when the reaction was conducted under solvent-free conditions. For example, the reaction gave a very low yield of the product when it was con-

\section{Table 1}

Optimization of reaction conditions for synthesis of compound $\mathbf{5 b}$ catalyzed by $\left\{\mathrm{Mo}_{132}\right\}$.

\begin{tabular}{lccccc}
\hline Entry & $\begin{array}{c}\text { Catalyst } \\
(\mathrm{g})\end{array}$ & Solvent & $T /{ }^{\circ} \mathrm{C}$ & $\begin{array}{c}\text { Time } \\
(\mathrm{min})\end{array}$ & $\begin{array}{c}\text { Isolated } \\
\text { yield (\%) }\end{array}$ \\
\hline 1 & - & - & 140 & 120 & 30 \\
2 & 0.10 & - & r.t. & 120 & - \\
3 & 0.04 & - & 100 & 90 & 59 \\
4 & 0.04 & - & 120 & 90 & 67 \\
5 & 0.04 & - & 140 & 90 & 85 \\
6 & 0.06 & - & 100 & 90 & 70 \\
7 & 0.06 & - & 120 & 90 & 82 \\
8 & 0.06 & - & 140 & 75 & 86 \\
9 & 0.08 & - & 100 & 90 & 74 \\
10 & 0.08 & - & 120 & 80 & 87 \\
11 & 0.08 & - & 140 & 60 & 89 \\
12 & 0.10 & - & 100 & 80 & 81 \\
13 & 0.10 & - & 120 & 60 & 90 \\
14 & 0.10 & - & 140 & 50 & 97 \\
15 & 0.10 & - & 150 & 50 & 96 \\
16 & 0.15 & - & 150 & 60 & 96 \\
17 & 0.10 & $\mathrm{H}_{2} \mathrm{O}$ & reflux & 300 & 11 \\
18 & 0.10 & $\mathrm{CH}_{3} \mathrm{OH}$ & reflux & 300 & 31 \\
19 & 0.10 & $\mathrm{CH}_{3} \mathrm{CH}_{2} \mathrm{OH}$ & reflux & 300 & 43 \\
20 & 0.10 & $\mathrm{CH}_{3} \mathrm{CN}$ & reflux & 300 & trace \\
\hline
\end{tabular}


ducted in the absence of the catalyst at $140{ }^{\circ} \mathrm{C}$ (Table 1 , entry 1 ), and gave no product when it was conducted in the presence of the catalyst at room temperature (Table 1, entry 2). These results therefore highlighted the importance of the catalyst loading and reaction temperature on the success of the reaction. Increases in the amount of the catalyst and reaction temperature up to $0.10 \mathrm{~g}$ and $140{ }^{\circ} \mathrm{C}$, respectively, led to an in- crease in the yield of the product $\mathbf{5 b}$, although further increases in these parameters did not lead to further improvements in the product yield or reaction time (Table 1, entries 15 and 16).

With the optimized conditions in hand, we proceeded to explore the scope of this $\left\{\mathrm{Mo}_{132}\right\}$-catalyzed reacting of $\mathbf{1}$ and $\mathbf{4}$ with a range of other aromatic aldehydes 2 and primary amines 3 (Table 2). As shown in Table 2, the $\left\{\mathrm{Mo}_{132}\right\}$ catalyst efficiently

Table 2

Synthesis of 1,2,4,5-tetrasubstituted imidazoles 5a-5m using the $\left\{\mathrm{Mo}_{132}\right\}$ catalyst.

\begin{tabular}{|c|c|c|c|c|c|c|c|}
\hline \multirow{3}{*}{$\frac{\text { Entry }}{1}$} & \multirow{3}{*}{$\frac{\mathrm{Ar}}{\mathrm{C}_{6} \mathrm{H}_{5}}$} & \multirow{3}{*}{$\frac{\mathrm{R}^{\mathrm{a}}}{\mathrm{C}_{6} \mathrm{H}_{5}}$} & \multirow{2}{*}{ Product $^{b}$} & \multirow{3}{*}{$\begin{array}{c}\begin{array}{c}\text { Time } \\
(\mathrm{min})\end{array} \\
70\end{array}$} & \multirow{3}{*}{$\begin{array}{c}\begin{array}{c}\text { Isolated yield } \\
(\%)\end{array} \\
93\end{array}$} & \multicolumn{2}{|c|}{ Melting point $\left({ }^{\circ} \mathrm{C}\right)$} \\
\hline & & & & & & Found & Reported \\
\hline & & & $5 a$ & & & $213-216$ & $216-218$ [28] \\
\hline 2 & $4-\mathrm{ClC}_{6} \mathrm{H}_{4}$ & $\mathrm{C}_{6} \mathrm{H}_{5}$ & $5 \mathbf{b}$ & 50 & 97 & $153-155$ & $149-151$ [28] \\
\hline 3 & $4-\mathrm{ClC}_{6} \mathrm{H}_{4}$ & $4-\mathrm{ClC}_{6} \mathrm{H}_{4}$ & $5 c$ & 60 & 92 & 189-192 & $187-189$ [25] \\
\hline 4 & $4-\mathrm{ClC}_{6} \mathrm{H}_{4}$ & $\mathrm{C}_{6} \mathrm{H}_{5} \mathrm{CH}_{2}$ & $\mathbf{5 d}$ & 60 & 90 & $160-162$ & $162-165$ [28] \\
\hline 5 & $4-\mathrm{BrC}_{6} \mathrm{H}_{4}$ & $\mathrm{C}_{6} \mathrm{H}_{5} \mathrm{CH}_{2}$ & $5 e$ & 60 & 88 & $170-173$ & $172-175[26]$ \\
\hline 6 & $4-\mathrm{MeC}_{6} \mathrm{H}_{4}$ & $\mathrm{C}_{6} \mathrm{H}_{5}$ & $5 f$ & 75 & 91 & $188-190$ & $189-190$ [26] \\
\hline 7 & 4- $\mathrm{MeC}_{6} \mathrm{H}_{4}$ & $4-\mathrm{MeC}_{6} \mathrm{H}_{4}$ & $5 g$ & 60 & 92 & 192-194 & $188-191$ [25] \\
\hline 8 & $4-\mathrm{MeC}_{6} \mathrm{H}_{4}$ & $\mathrm{C}_{6} \mathrm{H}_{5} \mathrm{CH}_{2}$ & $5 h$ & 70 & 93 & $168-170$ & $167-168$ [24] \\
\hline 9 & $4-\mathrm{MeOC}_{6} \mathrm{H}_{4}$ & $\mathrm{C}_{6} \mathrm{H}_{5} \mathrm{CH}_{2}$ & $5 \mathbf{i}$ & 90 & 86 & $159-161$ & $161-162$ [26] \\
\hline 10 & $4-\mathrm{O}_{2} \mathrm{NC}_{6} \mathrm{H}_{4}$ & $\mathrm{C}_{6} \mathrm{H}_{5}$ & $5 \mathbf{j}$ & 30 & 94 & 191-193 & $192-194[34]$ \\
\hline 11 & $4-\mathrm{BrC}_{6} \mathrm{H}_{4}$ & $\mathrm{Me}$ & $5 \mathbf{k}$ & 75 & 88 & $200-202$ & $202-203[26]$ \\
\hline 12 & $4-\mathrm{MeC}_{6} \mathrm{H}_{4}$ & $\mathrm{Me}$ & 51 & 90 & 89 & $222-224$ & $222-223$ [24] \\
\hline 13 & 2-thienyl & $\mathrm{C}_{6} \mathrm{H}_{5}$ & $5 m$ & 30 & 93 & $242-244$ & $248-250$ [33] \\
\hline
\end{tabular}

Reaction conditions: benzil $(\mathbf{1}, 1 \mathrm{mmol})$, aromatic aldehyde $2(1 \mathrm{mmol})$, primary amine $3(1 \mathrm{mmol})$, ammonium acetate $(\mathbf{4}, 1 \mathrm{mmol})$ and $\{\mathrm{Mo} 132\}(0.1 \mathrm{~g}$. at $140{ }^{\circ} \mathrm{C}$ under solvent-free conditions.

${ }^{a}$ An aqueous solution of $\mathrm{MeNH}_{2}$ was used for $\mathbf{5 k}$ and $\mathbf{5 l}$.

${ }^{\mathrm{b}}$ All of the products were characterized by IR spectroscopy and a comparison of their melting points with those of the authentic samples. The structure of some of the products were also confirmed by ${ }^{1} \mathrm{H}$ NMR spectroscopy. 
Table 3

Comparison of the efficiencies of different catalysts for the one-pot four-component synthesis of 1,2,4,5-tetrasubstituted imidazoles.

\begin{tabular}{|c|c|c|c|c|c|c|}
\hline \multirow{2}{*}{ Catalyst } & \multicolumn{3}{|c|}{ Conditions } & \multirow{2}{*}{ Time (min) } & \multirow{2}{*}{ Yield (\%) } & \multirow{2}{*}{ Ref. } \\
\hline & Solvent & $T /{ }^{\circ} \mathrm{C}$ & Other & & & \\
\hline L-Proline & $\mathrm{MeOH}$ & reflux & - & $510-600$ & $76-88$ & [24] \\
\hline $\mathrm{K}_{5} \mathrm{CoW}_{12} \mathrm{O}_{40.3} 3 \mathrm{H}_{2} \mathrm{O}$ & - & 140 & - & $120-150$ & $80-95$ & [25] \\
\hline $\mathrm{NH}_{4} \mathrm{H}_{2} \mathrm{PO}_{4} / \mathrm{Al}_{2} \mathrm{O}_{3}$ & - & 130 & - & $90-180$ & $80-91$ & [26] \\
\hline Brönsted acidic ionic liquid & - & 140 & - & $120-150$ & $85-95$ & [27] \\
\hline $\mathrm{BF}_{3}-\mathrm{SiO}_{2}$ & - & 140 & - & 120 & $80-93$ & [28] \\
\hline Carbon-based solid acid & - & 130 & - & $60-120$ & $86-94$ & [29] \\
\hline $\mathrm{InCl}_{3} .3 \mathrm{H}_{2} \mathrm{O}$ & $\mathrm{MeOH}$ & r.t. & - & $360-540$ & $49-84$ & [30] \\
\hline $\mathrm{NaHSO}_{4} / \mathrm{SiO}_{2}$ & - & 140 & - & 120 & $85-92$ & [31] \\
\hline $\mathrm{H}_{6} \mathrm{P}_{2} \mathrm{~W}_{18} \mathrm{O}_{62 .} 24 \mathrm{H}_{2} \mathrm{O} / \mathrm{SiO}_{2}$ & - & 140 & - & 120 & $82-91$ & {$[32]$} \\
\hline $\mathrm{FeCl}_{3} /$ montmorillonite $\mathrm{K} 10$ & - & 80 & MW & $3-4$ & $78-89$ & [33] \\
\hline$p$-Dodecylbenzenesulfonic acid & $\mathrm{H}_{2} \mathrm{O}$ & reflux & - & 240 & $73-86$ & [34] \\
\hline Montmorillonite K10 supported titanium & - & 120 & - & $120-240$ & $68-84$ & [35] \\
\hline$\left\{\mathrm{Mo}_{132}\right\}$ & - & 140 & - & $20-80$ & $86-97$ & this work \\
\hline
\end{tabular}

catalyzed the condensation reactions of $1,2,3$, and 4 to give the desired products $\mathbf{5 a}-\mathbf{5 m}$ in high yields over relatively short reaction time. It is noteworthy that the products could be readily separated from the catalyst, making this method especially useful for the synthesis of a wide range of 1,2,4,5-tetrasubstituted imidazoles.

The results obtained in the current study using the $\left\{\mathrm{Mo}_{132}\right\}$ catalyst were compared with those previously reported for the synthesis of 1,2,4,5-tetrasubstituted imidazoles using a variety of different catalysts (Table 3). The results of this comparison revealed that the $\left\{\mathrm{Mo1}_{132}\right\}$ catalyst gave shorter reaction time than all of the other conditions (except for the reaction catalyzed by $\mathrm{FeCl}_{3} /$ montmorillonite $\mathrm{K} 10$ under microwave irradiation), as well as higher yields of the desired products.

The reusability of the catalyst $\left\{\mathrm{Mo}_{132}\right\}$ was also evaluated under the optimized reaction conditions. Upon completion of the reaction, the catalyst was recovered according to the procedure described in the experimental section. The recovered catalyst was washed with hot ethanol and then dried under vacuum at $50{ }^{\circ} \mathrm{C}$ for $1 \mathrm{~h}$ before being reused in the same reaction. The results of this reusability study revealed that the catalyst could be used at least four times with only a slight reduction in its activity (Fig. 4). Furthermore, the FT-IR spectra of the recovered catalyst (Fig. 2(2)-(4)) were almost identical to that of the fresh catalyst (Fig. 2(1)), which indicated that the struc-

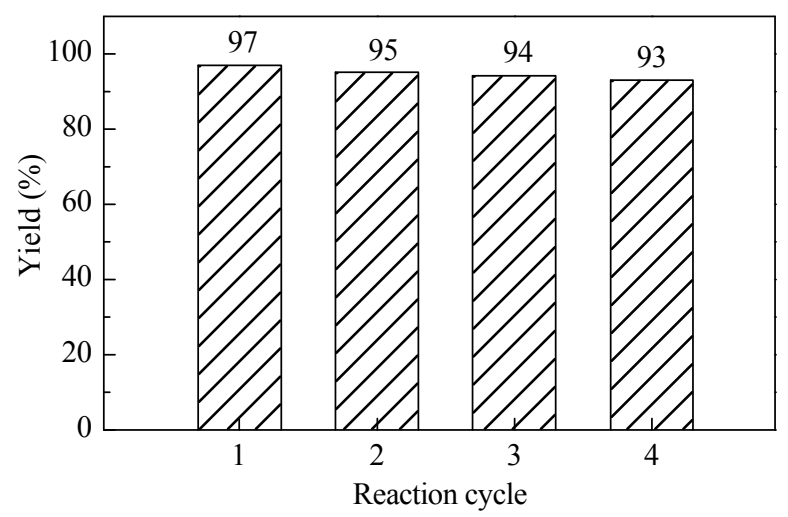

Fig. 4. Effect of recycling on the catalytic performance of $\left\{\mathrm{Mo}_{132}\right\}$ in the synthesis of $\mathbf{5 b}$. ture of the catalyst was unchanged by the reaction.

A plausible mechanism for the $\left\{\mathrm{Mo}_{132}\right\}$-catalyzed formation of the 1,2,4,5-tetrasubstituted imidazoles is shown in Scheme 2. The $\left\{\mathrm{Mo}_{132}\right\}$ catalyst has several accessible Mo sites and $\mathrm{NH}_{4}$ groups, which could act as Lewis acid and Brönsted acid centers, respectively, and therefore promote the reaction. The catalyst would play a significant role in increasing the electrophilic character of the electrophiles in the reaction. Ammonia could be released from the ammonium acetate in the reaction which could be detected using a $\mathrm{pH}$ indicator. When a piece of $\mathrm{pH}$ paper was held above the reaction mixture, a blue coloration was observed. This result indicated that the reaction proceeded by the initial nucleophilic attack of ammonia and the primary amine on the carbonyl group of the $\{\mathrm{Mo132}\}$-activated aldehyde with concomitant dehydration to give intermediate I. Intermediate I would then react with $\left\{\mathrm{Mo}_{132}\right\}$-activated benzil to afford intermediate II, which would be converted to intermediate III through a dehydration reaction. Finally, the dehydration of intermediate III would give the 1,2,4,5-tetrasubstituted imidazole product. According to this mechanism, the $\{\mathrm{Mo} 132\}$ catalyst would facilitate the formation of intermediates I, II, and III. Several attempts were made to isolate these intermediates under the optimized conditions, but all of these efforts were unsuccessful.

\section{Conclusions}

In conclusion, we have used the Keplerate-type giant nanoporous isopolyoxomolybdate $\left\{\mathrm{Mo}_{132}\right\}$ as an efficiently catalyst for the synthesis of 1,2,4,5-tetrasubstituted imidazoles in the one-pot, four-component reaction of benzil with an aromatic aldehyde, primary amine, and ammonium acetate under solvent-free conditions. This method provided the desired products in high yields over short reaction time, following a facile work-up process. Furthermore, the catalyst could be readily recycled, and reused at least three times without any discernible reduction in its catalytic activity. The procedure is also advantageous in the sense that it is a solvent-free reaction and therefore operates under environmentally friendly conditions. 


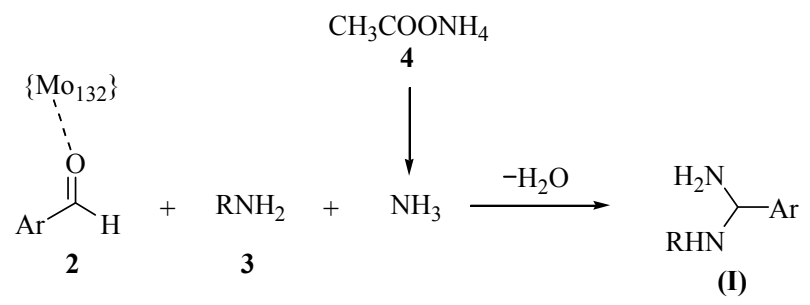<smiles>CCCCCCCCCCCC(=O)c1ccccc1</smiles><smiles>[R1]NC(N)[Al]CC</smiles>

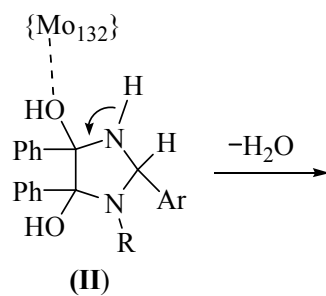

(I)

(III)

Scheme 2. Plausible mechanism for the $\left\{\mathrm{Mo}_{132}\right\}$-catalyzed formation of 1,2,4,5-tetrasubstituted imidazoles.

\section{Acknowledgment}

The authors express their gratitude to the Islamic Azad University, Mashhad Branch for its financial support.

\section{References}

[1] Müller A, Peters F, Pope M T, Gatteschi D. Chem Rev, 1998, 98: 239

[2] Pope M T, Müller A. Polyoxometalate Chemistry from Topology via Self-Assembly to Applications. Netherlands: Kluwer Academic Publishers, 2001

[3] Davoodnia A, Bakavoli M, Barakouhi Gh, Tavakoli-Hoseini N. Chin Chem Lett, 2007, 18: 1483

[4] Coronado E, Gomez-Garcia C J. Chem Rev, 1998, 98: 273

[5] Xie Y B. Adv Funct Mater, 2006, 16: 1823

[6] Ma Z, Liu Q Cui Z M, Bian S W, Song S G.J Phys Chem C, 2008, 112: 8875

[7] Zhang Y, Li D L, Chen Y, Wang X H, Wang S T. Appl Catal B, 2009, 86: 182

[8] Müller A, Krickemeyer E, Bögge H, Schmidtmann M, Peters F. Angew Chem Int Ed, 1998, 37: 3359

[9] Zhang L J, Xiong T A, Zhou Y S, Zhang L H. Chem Asian J, 2010, 5: 1984

[10] Polarz S, Smarsly B, Goltner C, Antonietti M. Adv Mater, 2000, 12: 1503

[11] Müller A, Das S K, Talismanov S, Roy S, Beckmann E, Bogge H, Schmidtmann M, Merca A, Berkle A, Allouche L, Zhou Y S, Zhang L J. Angew Chem Int Ed, 2003, 42: 5039

[12] Greedan J E. J Mater Chem, 2001, 11: 37

[13] Rezaeifard A, Haddad R, Jafarpour M, Hakimi M. J Am Chem Soc, 2013, 135: 10036

[14] Laufer S A, Zimmermann W, Ruff K J.J Med Chem, 2004, 47: 6311

[15] Antolini M, Bozzoli A, Ghiron C, Kennedy G, Rossi T, Ursini A. Bioorg Med Chem Lett, 1999, 9: 1023

[16] Ucucu U, Karaburun N G, Isikdag I. Farmaco, 2001, 56: 285

[17] Chang L L, Sidler K L, Cascieri M A, de Laszlo S, Koch G, Li B, MacCoss M, Mantlo N, O'Keefe S, Pang M, Rolando A, Hagmann W K. Bioorg Med Chem Lett, 2001, 11: 2549

[18] Murry J A. Curr Opin Drug Discov Dev, 2003, 6: 945

[19] Takle A K, Brown M J B, Davies S, Dean D K, Francis G, Gaiba A,
Hird A W, King F D, Lovell P J, Naylor A, Reith A D, Steadman J G, Wilson D M. Bioorg Med Chem Lett, 2006, 16: 378

[20] Chowdhury S, Mohan R S, Scott J L. Tetrahedron, 2007, 63: 2363

[21] Davoodnia A, Khojastehnezhad A, Bakavoli M, Tavakoli-Hoseini N. Chin J Chem, 2011, 29: 978

[22] Davoodnia A, Heravi M M, Rezaei-Daghigh L, Tavakoli-Hoseini N. Monatsh Chem, 2009, 140: 1499

[23] Bourissou D, Guerret O, Gabbai F P, Bertrand G. Chem Rev, 2000, 100: 39

[24] Samai S, Nandi G C, Singh P, Singh M S. Tetrahedron, 2009, 65: 10155

[25] Nagarapu L, Apuri S, Kantevari S.J Mol Catal A, 2007, 266: 104

[26] Emrani A, Davoodnia A, Tavakoli-Hoseini N. Bull Korean Chem Soc, 2011, 32: 2385

[27] Davoodnia A, Heravi M M, Safavi-Rad Z, Tavakoli-Hoseini N. Synth Commun, 2010, 40: 2588

[28] Sadeghi B, Mirjalili B B F, Hashemi M M. Tetrahedron Lett, 2008, 49: 2575

[29] Tavakoli-Hoseini N, Davoodnia A. Chin J Chem, 2011, 29: 203

[30] Sharma S D, Hazarika P, Konwar D. Tetrahedron Lett, 2008, 49:, 2216

[31] Karimi A R, Alimohammadi Z, Azizian J, Mohammadi A A, Mohammadizadeh M R. Catal Commun, 2006, 7: 728

[32] Karimi A R, Alimohammadi Z, Amini M M. Mol Divers, 2010, 14: 635

[33] Raghuvanshi D S, Singh K N. Indian J Chem B, 2010, 49: 1394

[34] Das B, Kashanna J, Kumar R A, Jangili P. Monatsh Chem, 2013, 144: 223

[35] Kannan V, Sreekumar K. J Mol Catal A, 2013, 376: 34

[36] Lantos I, Zhang W Y, Shui X Q, Eggleston D S. J Org Chem, 1993, 58: 7092

[37] Davidson D, Weiss M, Jelling M. J Org Chem, 1937, 2: 319

[38] Davoodnia A, Bakavoli M, Pooryaghoobi N, Roshani M. Heterocycl Commun, 2007, 13: 323

[39] Davoodnia A, Roshani M, Saleh-Nadim E, Bakavoli M, TavakoliHoseini N. Chin Chem Lett, 2007, 18: 1327

[40] Davoodnia A, Bakavoli M, Bashash M, Roshani M, Zhiani R. Turk J Chem, 2007, 31: 599

[41] Davoodnia A, Zhiani R, Tavakoli-Hoseini N. Monatsh Chem, 2008, 139: 1405

[42] Seifi N, Zahedi-Niaki M H, Barzegari M R, Davoodnia A, Zhiani R, 


\section{Graphical Abstract}

Chin. J. Catal., 2014, 35: 1761-1767 doi: 10.1016/S1872-2067(14)60174-1

\section{Application of a Keplerate type giant nanoporous isopolyoxomolybdate as a reusable catalyst for the synthesis of 1,2,4,5-tetrasubstituted imidazoles}

Ahmad Nakhaei, Abolghasem Davoodnia*

Mashhad Branch, Islamic Azad University, Iran
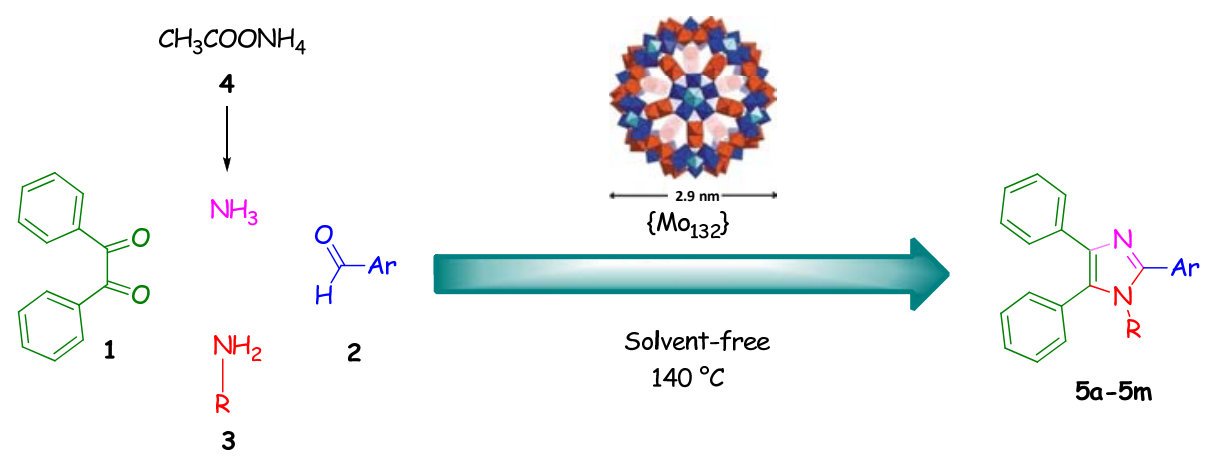

$\left\{\mathrm{Mo}_{132}\right\}$ efficiently catalyzed the synthesis of 1,2,4,5-tetrasubstituted imidazoles under solvent-free conditions. The method was relatively fast and high yielding, and the work-up was easy. The catalyst used at least four times without any substantial reduction in its catalytic activity.

Kaju A A. J Mol Catal A, 2006, 260: 77

[43] Zeinali-Dastmalbaf M, Davoodnia A, Heravi M M, Tavakoli-Hoseini N, Khojastehnezhad A, Zamani H A. Bull Korean Chem Soc, 2011, 32: 656

[44] Khojastehnezhad A, Davoodnia A, Bakavoli M, Tavakoli-Hoseini N, Zeinali-Dastmalbaf M. Chin J Chem, 2011, 29: 297

[45] Davoodnia A, Khojastehnezhad A, Tavakoli-Hoseini N. Bull Korean
Chem Soc, 2011, 32: 2243

[46] Davoodnia A, Zare-Bidaki A, Behmadi H. Chin J Catal (催化学报), 2012, 33: 1797

[47] Davoodnia A, Khojastehnezhad A. J Chil Chem Soc, 2012, 57: 1385

[48] Davoodnia A, Khashi M, Tavakoli-Hoseini N. Chin J Catal (催化学 报), 2013, 34: 1173 